Review Article

\title{
COVID-19: a dental perspective
}

\section{Paridhi Gupta ${ }^{1 *}$, Bhagyalakshmi A. ${ }^{1}$, Pranshu Mehta ${ }^{2}$}

\author{
${ }^{1}$ Department of Orthodontics, JSS Dental College and Hospital, Mysuru, Karnataka, India \\ ${ }^{2}$ Department of ENT, JSS Medical College and Hospital, Mysuru, Karnataka, India
}

Received: 02 April 2020

Accepted: 18 April 2020

\section{*Correspondence:}

Dr. Paridhi Gupta,

E-mail: pari_199311@yahoo.com

Copyright: () the author(s), publisher and licensee Medip Academy. This is an open-access article distributed under the terms of the Creative Commons Attribution Non-Commercial License, which permits unrestricted non-commercial use, distribution, and reproduction in any medium, provided the original work is properly cited.

\begin{abstract}
The novel coronavirus that has been posing threat and has caused a havoc all over the world. It has affected millions involving more than 200 countries and the death toll continuously increasing. Despite the efforts the outbreak is still on the rise owing to community spread. As of 9 April 2020, there have been 1,438,994 confirmed cases of COVID19 , including 85,586 deaths worldwide. COVID-19 although zoonotic in origin now is primarily transmitted form human-to-human. This article provides a brief overview of the etiology, pathophysiology, symptoms and management protocol in dentistry of this novel infection.
\end{abstract}

Keywords: COVID-19, Dentistry, Coronavirus, Pandemic, SARS-Cov-2

\section{INTRODUCTION}

Coronaviruses are large, enveloped single stranded RNA of the family coronaviridae. The beta-coronaviruses of this family include SARS-CoV (severe acute respiratory syndrome coronavirus) which was first identified in 2002 and the MERS-CoV (Middle East respiratory syndrome coronavirus) which was reported in 2012. ${ }^{1}$ Coronavirus is zoonotic in origin, Chinese horseshoe bats (Rhinolophus sinicus) being the most probable origin and once inside the human body it can spread from human to human by means of contact/respiratory droplets. ${ }^{2}$

\section{TERMINOLOGY}

Initially the disease was termed as NCIP (novel coronavirus-infected pneumonia) and the virus was called 2019-nCoV (2019 novel coronavirus) by the world health organization. ${ }^{3}$ Then in February 2020 WHO renamed the condition as COVID-19 (a short for of corona virus disease-19) and coronavirus study group (CSG) of the international committee on taxonomy of viruses renamed the virus SARS-CoV-2 (severe acute respiratory syndrome coronavirus 2). ${ }^{4}$

\section{EPIDEMIOLOGY}

As of 9 April 2020, there have been 1,438,994 confirmed cases of COVID-19, including 85,586 deaths worldwide. ${ }^{5}$ The R0 (basic reproduction number) of SARS-CoV-2 has been estimated between 2.2 and 3.28. 6,7 Every infected person a further infect 2-3 people on an average.

The median incubation period was estimated to be 5.1 days (95\% CI, 4.5 to 5.8 days), and $97.5 \%$ of those who develop symptoms will do so within 11.5 days (CI, 8.2 to 15.6 days) of infection. These estimates stated that, under conservative assumptions, 101 out of every 10,000 cases ( $99^{\text {th }}$ percentile) will develop symptoms after 14 days of active monitoring or quarantine. ${ }^{8}$

\section{ROUTE OF TRANSMISSION}

COVID-19 although zoonotic in origin now is primarily transmitted form human-to-human. It is transmitted by coming in contact with droplets of infected individuals' upper respiratory tract secretions during sneezing or coughing. ${ }^{9}$ 
A study revealed that pregnant ladies infected by SARSCoV-2 did not show any evidence of intrauterine transfer. ${ }^{10}$ Another study stated that there is no clear evidence regarding optimal delivery timing, the safety of vaginal delivery, or whether cesarean delivery prevents vertical transmission at the time of delivery. ${ }^{11}$

\section{SIGNS AND SYMPTOMS}

COVID-19 typically presents with systemic and/or respiratory manifestations. Some infected with SARS$\mathrm{CoV}-2$ are asymptomatic and can act as carriers. The various symptoms are as follows. ${ }^{9}$

\section{Common}

Fever, cough, fatigue, sputum production, and shortness of breath.

\section{Less common}

Myalgia/arthralgia, headaches, and sore throat.

Patients also showed bilateral pneumonia, with groundglass opacity and bilateral patchy shadows being the most common patterns on $\mathrm{CT}$.

\section{DIAGNOSIS}

The definitive test for SARS-CoV-2 is the real-time reverse transcriptase-polymerase chain reaction (RTPCR) test and is believed to have high specificity but low sensitivity leading to increased chances of a false negative test and hence more than one test is required to confirm the diagnosis. ${ }^{12,13}$

\section{LABORATORY FINDINGS}

A study conducted on hospitalized patients demonstrated the following findings..$^{9,14}$

- Lymphopenia

- Increased prothrombin time (PT)

- Increased lactate dehydrogenase

- Mild increase in CRP (C-reactive protein) and ESR (erythrocytic sedimentation rate).

\section{PATHOPHYSIOLOGY}

SARS-CoV-2 virus, is closely-related to MERS and SARS coronaviruses and it attaches through its $\mathrm{S}$ protein (spike protein) to the angiotensin-converting enzyme 2 (ACE 2) receptor. These receptors are commonly found on the alveolar cells lining the epithelium of the lungs. The cardiovascular involvement is also due to the presence of these receptors in the cardiovascular system. ${ }^{15}$

\section{PROPOSED DRUGS FOR COVID-19}

Various drugs that have been proposed to be effective for treatment of this infection are as follows. ${ }^{16}$ Lopinavir, hydroxychloroquine, azithromycin, oseltamavir, and protease inhibitors.

\section{PATIENT MANAGEMENT AND PREVENTION IN A DENTAL SETUP}

On an average people touch their face 23 per hour, $44 \%$ of this involves the mucous membranes of mouth or nose. ${ }^{17}$ Due to its spread by contact and droplets of saliva dental healthcare professionals are at a high risk of this nosocomial infection and can become potential carriers of the disease. Various preventive measures required for a dental setup during this epidemic are:

\section{Screening}

Initial screening over telephonic conversation can be done before scheduling any emergency cases. Patient should be asked about their travel history, contact with a known case of COVID-19, present of any respiratory symptoms like coughing, fever etc., and patients falling in any of the above-mentioned categories should be deferred from treatment unless it is an emergency.

\section{Evaluating the patient}

Patients should be requested to wear a surgical mask and follow proper hand hygiene protocols while visiting the hospital. Patients should be asked fill up a COVID-19 questionnaire in order to enquire detailed medical and dental history. To evaluate the severity of the problem and if at all the patient is a suspect of COVID-19. Even in the waiting room patients should be asked to maintain a minimum distance of 6 feet from each other. Patient's body temperature using a non-contact forehead thermometer or with cameras having infrared thermal sensors should be measured. ${ }^{18}$ Patients who present with fever $\left(>100.4^{\circ} \mathrm{F}=38^{\circ} \mathrm{C}\right)$ and/or respiratory disease symptoms, should have elective dental care deferred for at least (2-3) weeks.

\section{Management}

Pharmacological management of infections in the form of antibiotics and pain killers can provide symptomatic relief until treated otherwise. It will also provide dental professionals enough time to reschedule the appointment and screen emergency cases. Mouth rinse before starting the procedure with povidone iodine. Studies have shown that $0.2 \%$ povidone-iodine might reduce the load of corona viruses in saliva. ${ }^{18,19}$

Dentists should follow the standard precautions including the appropriate use of personal protective equipment (PPE) that is, medical mask, gown, gloves, and eye protection (aerosol-generating procedures require N95 
masks and aprons along with hand hygiene practices. Proper manner of wearing and removal of PPE should be followed as given by CDC. ${ }^{20}$

Rubber dam should be used whenever possible during procedure to minimize the spread of splatter. Minimize the use of high-speed handpieces, three-way syringes and ultrasonic interments as they generate a lot of aerosols. Use of disposable instruments like mouth mirrors should be used to minimize exposure.

Extraoral radiographs like panoramic radiograph should be preferred over intraoral radiographs to avoid the gag reflex or cough that may occur while during radiation exposure. When intraoral imaging is mandatory, sensors should be double barriered to prevent crosscontamination. $^{21}$

SARS CoV-2 can remain viable in aerosol and survive up to 3 days on inanimate surfaces at room temperature, with a greater preference for humid conditions. ${ }^{22}$ Hospitals and dental setup should be disinfected using (62-71) \% ethanol, $0.5 \%$ hydrogen peroxide or $0.1 \%$ sodium hypochlorite which were recommended for SARS and MERS due to the close similarity between them and SARS CoV-2. ${ }^{23}$

\section{RECOMMENDATIONS FOR DENTAL EDUCATION}

Education acts as a challenge for medical and dental schools during this outbreak period. Online lectures, case studies, and problem-based learning tutorials should be adopted to avoid unnecessary aggregation of people and associated risk of infection. ${ }^{24}$ Existing smartphones and applications have made it possible for education to reach every corner of the world whenever possible.

\section{DISCUSSION}

World wide spread of SARS CoV-2 has affected the world economy in every manner. Until this cloud of pandemic takes a permanent halt all dental professionals should defer all elective treatment. Emergency procedures should be carried out following universal precautions and proper screening of patients. Some of the patients are asymptomatic with COVID-19 infections since the incubation period can range from 0 to 24 days and most patients only develop mild symptoms while some can be carriers too, hence considered as potentially infected by this virus. ${ }^{25}$ As health care professionals it is our duty to protect the public and maintain high standards of care and infection control and serve in every manner possible during these challenging times.

Funding: No funding sources Conflict of interest: None declared

Ethical approval: Not required

\section{REFERENCES}

1. Wax RS, Christian MD. Practical recommendations for critical care and anaesthesiology teams caring for novel coronavirus (2019-nCoV) patients. Can J Anaesth. 2020;12:1-9.

2. Chan JF, Yuan S, Kok KH, To KK, Chu H, Yang J, et al. A familial cluster of pneumonia associated with the 2019 novel coronavirus indicating personto-person transmission: a study of a family cluster. Lancet. 2020;395(10223):514-23.

3. Zhu N, Zhang D, Wang W, Li X, Yang B, Song J, et al. A Novel Coronavirus from Patients with Pneumonia in China, 2019. N Engl J Med. 2020;382:727-33.

4. Gorbalenya AE. Severe acute respiratory syndromerelated coronavirus: The species and its viruses, a statement of the Coronavirus Study Group. Alexander E Gorbalenya bio Rxiv. 2020;32(4):1-9.

5. WHO Health Emergency Dashboard WHO (COVID-19) Homepage.

6. Liu Y, Gayle AA, Smith WA, Rocklov J. The reproductive number of COVID-19 is higher compared to SARS coronavirus. J Travel Med. 2020;27(2):pii:taaa021.

7. Li Q, Guan X, Wu P, Wang X, Zhou L, Tong Y, et al. Early Transmission Dynamics in Wuhan, China, of Novel Coronavirus-Infected Pneumonia. New England J Med. 2020;382:1199-207.

8. Lauer SA, Grantz KH, Bi Q, Jones FK, Zheng Q, Meredith HR, et al. The Incubation Period of Coronavirus Disease 2019 (COVID-19) From Publicly Reported Confirmed Cases: Estimation and Application. Annals Internal Med. 2020.

9. Wang D, Hu B, Hu C, Zhu F, Liu X, Zhang J, et al. Clinical Characteristics of 138 Hospitalized Patients With 2019 Novel Coronavirus-Infected Pneumonia in Wuhan, China. JAMA. 2020.

10. Heymann DL, Shindo N. COVID-19: What Is Next for Public Health? (2020) Lancet. Available at: https://pubmed.ncbi.nlm.nih.gov/32061313-covid19-what-is-next-for-public-health/?from term=covid and from_pos=2. Accessed on 3 March 2020.

11. Chen D, Yang H, Cao Y, Cheng W, Duan T, Fan C, et al. Expert consensus for managing pregnant women and neonates born to mothers with suspected or confirmed novel coronavirus (COVID-19) infection. Int J Gynaecol Obstet. 2020;149(2):130-6.

12. Kanne JP, Little BP, Chung JH, Elicker BM, Ketai LH. Essentials for Radiologists on COVID-19: An Update-Radiology Scientific Expert Panel. Radiology. 2020.

13. Basha MM, Meltzer CC, Kim DC, Tuite MJ, Kolli KP, Tan BS. Radiology Department Preparedness for COVID-19: Radiology Scientific Expert Panel. Radiology. 2020.

14. Rodrigues JCL. An update on COVID-19 for the radiologist - A British society of Thoracic Imaging statement. Clinical Radiology. 2020. 
15. Zheng YY, Ma YT, Zhang JY, Xie X. COVID-19 and the cardiovascular system. Nature reviews. Cardiology; 2020.

16. Mehta P, Bharathi MB. Proposed drug interventions for SARS CoV 2 infection. Int J Res Med Sci. 2020;8:1-7.

17. Kwok YLA, Gralton J, McLaws ML. Face touching: A frequent habit that has implications for hand hygiene. Am J Infect Control. 2015;43:112-4.

18. Peng X, Xu X, Li Y. Transmission routes of 2019$\mathrm{nCoV}$ and controls in dental practice. Int J Oral Sci. 2020;12:9.

19. Kariwa H, Fujii N, Takashima I. Inactivation of SARS coronavirus by means of povidone-iodine, physical conditions, and chemical reagents. Jpn J Vet Res. 2004;52:105-12.

20. Centers for Disease Control and Prevention. Infection control: severe acute respiratory syndrome coronavirus 2 (SARS-CoV-2). Available at: https://www.cdc.gov/coronavirus/2019-ncov/ infection-control/control-recommendations.html. Accessed on 9 March 2020.

21. List N: EPA's registered antimicrobial products for use against novel coronavirus SARS-CoV-2, the cause of COVID-19. Washington, DC: United States Environmental Protection Agency. Available at: https://www.epa.gov/pesticide-registration/list-ndisinfectants-use-against-sars- cov-2. Accessed on 18 March 2020.

22. Doremalen VN, Bushmaker T, Morris DH. Aerosol and surface stability of HCoV-19 (SARS-CoV-2) compared to SARS-CoV-1. N Engl J Med. 2020.

23. Kampf G, Todt D, Pfaender S, Steinmann E. Persistence of coronaviruses on inanimate surfaces and its inactivation with biocidal agents. J Hosp Infect. 2020;104:246-51.

24. Patil N, Chan Y, Yan H. SARS and its effect on medical education in Hong Kong. Med Educ. 2003;37(12):1127-8.

25. Rothe C, Schunk M, Sothmann P. Transmission of 2019-nCoV infection from an asymptomatic contact in Germany. N Engl J Med. 2020;382:970-1.

Cite this article as: Gupta $\mathrm{P}$, Bhagyalakshmi $\mathrm{A}$ Mehta P. COVID-19: a dental perspective. Int J Community Med Public Health 2020;7:1994-7. 